\title{
Knowledge and practice of nursing professionals about prophylaxis of ophthalmia neonatoruma
}

\author{
Conhecimento e prática de profissionais de enfermagem sobre profilaxia da oftalmia neonatal
} Conocimiento y la práctica de profesionales de enfermería sobre profilaxis de la oftalmía neonatal

\author{
Fernanda Carla Pereira Duarte ${ }^{1}($ D) \\ Fernanda Garcia Bezerra Góes ${ }^{1}$ (1) \\ Juliana Rezende Montenegro Medeiros \\ de Moraes $^{2}$ \\ Laura Johanson da Silva $^{3}$ \\ Liliane Faria da Silva ${ }^{4}$ (D) \\ Maria da Anunciação Silva ${ }^{1}$ (1)
}

1. Universidade Federal Fluminense.

Rio das Ostras, RJ, Brasil.

2. Universidade Federal do Rio de Janeiro.

Rio de Janeiro, RJ, Brasil.

3. Universidade Federal do Estado do Rio de Janeiro. Rio de Janeiro, RJ, Brasil.

4. Universidade Federal Fluminense.

Niterói, RJ, Brasil.
Corresponding author:

Fernanda Garcia Bezerra Góes.

E-mail: ferbezerra@gmail.com

Submitted on $07 / 13 / 2018$

Accepted on 10/15/2018.

DOI: 10.1590/2177-9465-EAN-2018-0212

\section{Abstract}

Objective: To analyze the knowledge and practice of nursing professionals about the prophylaxis of ophthalmia neonatorum. Method: Descriptive study, of qualitative approach, carried out in the first semester of 2018, in a city hall hospital located in the lake area of the Rio de Janeiro's state, through semi-structured interviews with 14 Nursing professionals participating in the care of the newborn, whose data were submitted to the Thematic Analysis. Results: From the three emerging thematic categories, there are gaps in knowledge related to ophthalmia neonatorum, silver nitrate and the instillation procedure of this prophylactic solution, as well as differences in care practice regarding care before, during and after the procedure. Conclusion and implications for practice: The data point to the importance of training the Nursing team in the prophylaxis of ophthalmia neonatorum, the revision of guidelines and procedures aimed at standardizing the procedure, as well as emphasizing the need for adequate follow-up of pregnant women in prenatal care.

Keywords: Newborn; Ophthalmia Neonatorum; Neonatal Nursing; Nursing Care; Knowledge.

\section{Resumo}

Objetivo: Analisar o conhecimento e a prática de profissionais de Enfermagem sobre profilaxia da oftalmia neonatal. Método: Estudo descritivo, de natureza qualitativa, realizado no primeiro semestre de 2018, em um hospital municipal localizado na baixada litorânea do estado do Rio de Janeiro, por meio de entrevistas semiestruturadas com 14 profissionais de Enfermagem, que participam da assistência ao recém-nascido, cujos dados foram submetidos à Análise Temática. Resultados: A partir das três categorias temáticas emergentes evidenciaram-se lacunas no conhecimento relacionadas à oftalmia neonatal, ao nitrato de prata e ao procedimento de instilação dessa solução profilática, além de divergências na prática assistencial quanto aos cuidados antes, durante e após a realização do procedimento. Conclusão e implicações para a prática: Os dados apontam para a importância da capacitação da equipe de Enfermagem para a realização da profilaxia da oftalmia neonatal, da revisão de diretrizes e condutas que visem a padronização do procedimento, além de ressaltar a necessidade de um acompanhamento adequado das gestantes no pré-natal.

Palavras-chave: Recém-nascido; Oftalmia Neonatal; Enfermagem Neonatal; Cuidados de Enfermagem; Conhecimento.

\section{REsumen}

Objetivo: Analizar el conocimiento y la práctica de los profesionales de Enfermería sobre la profilaxis de la oftalmía neonatal Método: Estudio descriptivo, de naturaleza cualitativa, realizado en el primer semestre de 2018, en un hospital municipal ubicado en la bajada costera del estado de Río de Janeiro, a través de entrevistas semiestructuradas desarrolladas con 14 profesionales de Enfermería, que participan en la asistencia al recién nacido, cuyos datos se sometieron al análisis temático. Resultados: $\mathrm{A}$ partir de las tres categorías temáticas emergentes se evidencian lagunas en el conocimiento relacionadas a la oftalmía neonatal, al nitrato de plata y al procedimiento de instilación de esa solución profiláctica, además de divergencias en la práctica asistencia en cuanto a los cuidados antes, durante y después de la realización del procedimiento. Conclusión y las implicaciones para la práctica: Los datos apuntan a la importancia de la capacitación del equipo de Enfermería para la realización de la profilaxis de la oftalmia neonatal, de la revisión de directrices y conductas que visen la estandarización del procedimiento, además de resaltar la necesidad de un acompañamiento adecuado de las gestantes en el prenatal.

Palabras clave: Recién nacido; Oftalmía Neonatal; Enfermería Neonatal; Cuidados de Enfermería; Conocimiento. 


\section{INTRODUCTION}

Ophthalmia neonatorum or neonatal conjunctivitis are terms used to describe conjunctivitis distinguished by erythema, edema and purulent drainage that affects newborns, usually contracted during birth, by contact with maternal secretions contaminated by different microbial agents,,$^{1-3}$ especially those transmitted sexually. Even though its risk is higher in normal births, there are cases of ocular infection in cesarean sections, especially in prolonging membranes rupture. ${ }^{2}$ Thus, its occurrence reflects the local epidemiology of untreated sexually transmitted infections (STIs) during pregnancy. ${ }^{4}$

Worldwide, the prevalence of STIs remains high, with an incidence of 1 million cases in 2012, of which 210,000 are due to chlamydia or gonorrhea. Ninety-one percent of these infections are in low and middle-income countries, ${ }^{4}$ of which Brazil is included. However, national data on the incidence and prevalence of these STIs are scarce in view of the inadequacy and fragility of epidemiological surveillance due to the greater coverage of compulsory notification of diseases that pose greater risks to the community such as syphilis, viral hepatitis and HIV/AIDS. ${ }^{5}$

It should be noted that ophtalmia neonatorum is an aggravating factor to the health of the newborn, due to the risks of eye perforation and blindness, caused by Neisseria gonorrhoeae in its most severe form and Chlamydia trachomatis, in its most common form. ${ }^{2}$ It is estimated that ophthalmia neonatorum annually causes blindness in more than 10,000 newborns all over the world. ${ }^{1}$

In addition to the most prevalent agents, other bacterial etiological agents may also cause ophthalmia neonatorum, such as Haemophilus species, Streptococcus pneumonia, Staphylococcus aureus, Staphylococcus epidermidis, Streptococcus viridians, Escherichia coli, Pseudomonas aeruginosa, among others, in addition to herpes simplex virus type 2 and adenovirus, as well as chemical processes, especially for the use of silver nitrate. ${ }^{3}$ Due to the variety of causative agents, national and international guidelines regarding the management of STIs recommend among the good practices that the diagnosis of ophthalmia neonatorum should be performed from the use of smears stained with conjunctival secretions by the Gram's method, given its good specificity and sensitivity. ${ }^{6,7}$

If there is only the clinical diagnosis, treatment should be directed to gonorrhea and chlamydia, with the evaluation of a possible systemic infection. In this regard, in Brazil, the Ministry of Health recommends the use of Ceftriaxone in a single dose, intramuscularly. ${ }^{6}$

For centuries, ophthalmia neonatorum was seen as a public health problem worldwide. In Europe, at the end of the $19^{\text {th }}$ century, its prevalence in live births exceeded the rate of $10 \%$, of which $20 \%$ had a corneal lesion and $3 \%$ had blindness. In 1881, physician Carl Credé discovered a prophylactic form by noting that using silver nitrate at $2 \%$ in newborn's eyes, shortly after birth, reduced the incidence of the disease considerably. Soon after, its formula was modified to $1 \%$ due to its lower toxicity. In Brazil, compulsory use was regulated by Executive Order 9713/77, later supplemented by Executive Order 19941/82. ${ }^{2}$

Currently, there is controversy over its use, due to its ineffectiveness against the most common etiological agent of the disease, Chlamydia trachomatis, and its effect of irritation, which may cause chemical conjunctivitis. ${ }^{1,2,4}$ Thus, in recent years, in some Brazilian maternity wards, their use was replaced by silver vitelinate at $10 \%$, which is less toxic, has low cost and proven prophylaxis against chlamydia, but with a significantly lower efficacy than silver nitrate, and for this reason, its use is not officially recommended. On the other hand, units started using iodopovidone at $2.5 \%$, which, among other characteristics, also is of low toxicity, action against chlamydia, does not induce microbial resistance, besides being considered inexpensive and of superior efficacy in relation to silver vitelinate at $10 \% .^{1,2}$

A meta-analysis of the effectiveness of ocular prophylaxis by agents used to prevent ophthalmia neonatorum caused by gonococci and chlamydia has concluded that both erythromycin and iodopovidone are more effective than silver nitrate in preventing this condition. ${ }^{8}$ In this logic, in the United States, the only antibiotic ointment recommended for use in neonates for prophylaxis of ophthalmia neonatorum is erythromycin, while silver nitrate is no longer manufactured in this country. ${ }^{7,9} \mathrm{In}$ Brazil, the Ministry of Health recommends the use of erythromycin ointment at $0.5 \%$ and tetracycline $1 \%$ as an alternative, noting that silver nitrate at $1 \%$ should be reserved only if the health unit does not have the other two substances. ${ }^{10}$

However, many maternity hospitals in Brazil, including in the state of Rio de Janeiro, still use silver nitrate at $1 \%$, the Credé's Method, as the standard choice for the prevention of neonatal conjunctivitis. However, its use requires specific care ranging from bottle storage ${ }^{2}$ to its application, ${ }^{11}$ so that the incidence of the disease is reduced without additional damage to the newborn.

Thus, it is noted that the prophylaxis of ophthalmia neonatorum requires adequate knowledge and practice of health professionals, including the Nursing team, considering its importance for the reduction of blindness and visual loss in children, as part of a global policy of eye health. ${ }^{4} \mathrm{It}$ is necessary to emphasize the performance of Nursing in the context of direct care for newborn, immediately after birth and in the first hours of his/her life. In addition, the way of caring is influenced by knowledge patterns and practice established in the daily lives of the different health services, which are not always the best practices recommended in the literature, imposing the constant need to update scientific technical knowledge aiming at the quality and safety of care.

Seen that, research aimed to analyze the knowledge and practice of Nursing professionals on prophylaxis of ophthalmia neonatorum. 


\section{METHOD}

Descriptive, qualitative study, ${ }^{12}$ carried out at the Surgical Center and Joint Housing of a city hall general hospital, located in the lake area of the state of Rio de Janeiro, Brazil. It is noteworthy that this hospital is a field of practice of the Nursing undergraduate course of a federal public university of the same state. Fourteen Nursing professionals participated in the study, who were in the direct care of the newborn, excluding professionals who were on vacation or sick leave. Of the invited professionals, only one professional refused to participate in research due to fatigue. Among those who accepted, there was no dropout.

Individual face-to-face interviews were conducted through a semi-structured script, composed of an initial part with the characterization of the participants and another with questions directed to the objective of the study, namely: knowledge about Ophthalmia Neonatorum/Conjunctivitis and the method used for its prevention, focused on concentration; time of change and complications in the use of the solution, besides care taken before, during and after its application; and, the preparation for the practice.

The interviews were recorded in digital media, from April to June 2018, in a quiet and discrete environment of the institution itself, with the presence of the interviewee and the interviewer. In the end, the participant was given a refund by any doubts that arose at the time of the interview. Each meeting lasted approximately 15 minutes with each professional. The number of participants was delimited by the theoretical saturation of data, since no new elements were found in the statements, given the regularity of the findings. ${ }^{13}$

After the complete transcription of the interviews, the empirical data generated were submitted to the Thematic Analysis in its three stages. In the pre-analysis, floating readings of the set of statements and the primary classification of data occurred, from the colorimetric marking of the units of record, that is, of words, excerpts and sentences with the same initial meaning and their due allocation by color in an analytical framework. In the second step, material exploration, the content was effectively categorized, aiming at reaching the nucleus of text comprehension, through the aggregation of different sense nuclei previously identified. In the third step, the treatment of data obtained and its interpretation, the results were presented with a cursive description of the findings, based on interpretations, on the participants' speeches, with further discussion based on the best scientific evidence on the subject. ${ }^{14}$

The project was submitted to the Research Ethics Committee (Comitê de ética em Pesquisa - CEP) of Universidade Federal Fluminense (UFF) and approved in December 2017 (CAAE: 79891417.6.0000.5243/Opinion:2.445.323). Data were collected after signing the Informed Consent Term and Voice Record Authorization Term, assuring all participants the secrecy and anonymity of information according to the recommendations of Resolution
466/12 of the National Health Council. An alphanumeric code was used with the initials of their professions and the interview order to ensure anonymity.

\section{RESULTS}

Fourteen Nursing professionals participated in the study, among them five nurses (35.7\%), eight Nursing technicians (57.1\%) and one Nursing Assistant (7.2\%). Of the participants, 13 were women $(92.8 \%)$ and only 1 man $(7.2 \%)$, with ages varying from 33 to 52 . The training time ranged from 11 to 30 years.

The analysis of data originated the thematic categories: knowledge of Nursing professionals about ophthalmia neonatorum, knowledge of nursing professionals about silver nitrate and practice of Nursing professionals in the prophylaxis of ophthalmia neonatorum.

\section{Knowledge of nursing professionals on ophthalmia neonatorum}

Regarding the causes of ophthalmia neonatorum, four professionals correlated it with conjunctivitis in the first month of life of the baby due to gonorrhea, contracted during vaginal delivery. Only one participant also cited as a cause the chlamydia infection, as well as the non-treatment of women for these infections.

It is caused by gonococcus bacteria where it can cause conjunctivitis in the baby, ophthalmia, which is transmitted to the baby at the time of birth. (TE7)

A conjunctivitis usually appearing in the first month of life, contracted through delivery in the vaginal canal of mothers who are not treated for gonorrhoea and chlamydia. (E1)

Still about the causes, three professionals reported that ophthalmia neonatorum is transmitted by vaginal secretions during regular delivery, without specifying any microbial agent related to the contamination of these maternal discharge.

\section{The cause is the mother's vaginal discharge. (TE2)}

It is a conjunctivitis, many children get when passing through the birth canal. (E5)

Only one nurse referred, in her speech, that the cause of ophthalmia neonatorum is viral or bacterial. However, inaccurately, pointed out that the lack of hand hygiene is solely responsible for its transmission.

It is viral or bacterial. [...] It happens due to lack of hand hygiene [...] usually by contact, and it ends up having even an outbreak of neonatal conjunctivitis. (E4) 
The answers showed that six professionals did not know the causes of this disease in the neonates, as they did not specify in their testimonies any causative agent. It is also worth mentioning that in no response of the participants other possible bacterial, viral or chemical agents were mentioned for causing ophthalmia neonatorum, as well as the possibility of transmission by cesarean section.

I believe it is the handling here at the time of birth. (AE1)

There you have something I don't even think about. (TE5)

As for the other knowledge variables analyzed, regarding the prevention/prophylaxis of ophthalmia neonatorum, the great majority, namely eleven professionals, made a direct and exclusive association of the use of silver nitrate, Credé's Method, at the time of delivery to prevent this condition among newborns. Only one nurse specified that this technique especially prevents gonococcal conjunctivitis.

\section{Preventing using silver nitrate. (TE2)}

Credé's Method mostly prevents gonococcal conjunctivitis. (E2)

It was also noted that three professionals attributed the prevention of ophthalmia neonatorum exclusively to washing (sanitizing) the hands, avoiding scratching the eyes and cleaning the eyes with saline solution. In addition, no professional referred to the importance of prevention, early detection and appropriate treatment of Sexually Transmitted Infections to minimize the occurrence of this type of problem.

Yes, actually, it's hand washing or sanitizing and avoid itching eyes. (E4)

Yes, cleansing with saline solution, eye cleaning. (E5)

The present study also questioned the treatment of this infectious disease. However, it was verified by the group of statements that seven professionals could not report how ophthalmia neonatorum can be treated, and one professional mistakenly pointed out that the treatment would be exclusively with saline solution.

Uh-oh, I don't know, don't remember. (E1)

A saline solution is enough, right? No big deal. (TE1)

Six professionals pointed out that the baby diagnosed with this type of conjunctivitis should receive antibiotic treatment prescribed by the physician, and only two of these participants explained the use topically (eye drops) and/or intravenous, and one signaled the systemic route without specifying the route of administering the drug in such cases.
Usually, the pediatrician will diagnose and prescribe antibiotic. (TE2)

You administer eye drops [...] or venous antibiotic. (E5)

We administer that eye drop of ciprofloxacin or gentamicin [...] Besides the topic we do the systemic. (E2)

A nodal question raised by two nurses is the need for a bacterial culture test, with the use of the swab, to precisely select the drug treatment. However, E2 signaled the absence, in the institution, of this examination to identify specifically the etiological agent:

Sometimes we get a kind of neonatal conjunctivitis here. But we do not have a culture in the hospital to identify which conjunctivitis this is. (E2)

Finally, in the categorization of speeches, as for the possible complications that ophthalmia neonatorum can cause to newborns, it was verified that four Nursing professionals did not know how to describe them and another three indicated the term infection as a complication of the disease, without further clarification.

Hmm, complications? I don't know what they are. (E3)

Infection and possible death. (TE2)

However, seven professionals asserted blindness as the main complication of ophthalmia neonatorum. Of these, three were insecure when responding and no one mentioned the risk of corneal lesions.

If not treated it could cause blindness to the newborn. (E1)

I don't know, I guess even blindness, isn't it? (TE7)

\section{Knowledge of nursing professionals on silver nitrate}

Considering that prophylaxis with silver nitrate was the only form of prevention of ophthalmia neonatorum reported by the participants of research, being the institutional routine, the aggregation of the testimonies in this category was about the professionals' knowledge about this prophylactic agent. In this logic, six professionals cited, even though they had questions, the correct concentration of silver nitrate at $1 \%$ to be used in newborns.

It is silver nitrate at $1 \%$ and it serves as an antibiotic. (E2) Concentration... I don't know if it is at 1\%, don't know. (TE3)

Continuously, from the grouping of textual fragments, it was verified that eight professionals could not indicate the adequate concentration of this solution for the prophylaxis of ophthalmia 
neonatorum, among these, two erroneously indicated that it would be at $2 \%$.

\section{Hmm, I don't know it by heart. (E3) \\ Now I don't remember, I guess it is at $2 \%$. (TE2)}

Regarding the time of solution change, the fourteen professionals could not distinguish the correct time for the open bottle to be replaced by another, but most professionals associated this time with the date of expiry of the prophylactic agent. According to them, as the use of the solution in their sector is frequent, the bottle is only replaced at the end of the substance. A nurse also informed that the change time is one week.

So, the solution you have there is like an eyedropper, I don't know, I'm not sure what it is, after l open I don't know for how long it is used. (E4)

It comes with a date of expiry and we respect it. And as there are many births there is no time to expire or exceed the time. (TE7)

A week. (E5)

Regarding the complications of silver nitrate use, eight professionals stated that they did not know the problems that this prophylactic agent can cause to the newborn. Two professionals indicated that they knew that this substance is being replaced in other institutions by other solutions, but without specifying the reasons for it and by which substance it is being replaced.

\section{No, I'd even like to know it. (TE1)}

Look, I don't remember, but I think that's even why they are changing it, in some places they don't even use it anymore, right? (E1)

Nevertheless, in a vague and uncertain manner, five participants suggested different complications such as toxicity, eyelid swelling, neonatal conjunctivitis, partial or total burn of or visual impairment (blindness) may be related to the use of silver nitrate, including overuse.

I guess there must be toxicity, right? I don't know, but I guess so. (E2)

Sometimes we realize that some babies get swollen eyelids. (TE8)

I think that's it, right? Neonatal conjunctivitis. (AE1)

I think it can cause a lot of burns. (E3)

I don't know, maybe the excessive use of it, like putting two drops or a little more, and it may end up causing blindness in the child or partial visual impairment. (TE3)
Only one nurse mentioned chemical pink eye (conjunctivitis) as a complication of the use of silver nitrate, characterizing it as a conjunctivitis with secretion and watery eyes, besides mentioning that in the institution it is treated with saline solution, due to the rapid evolution towards cure.

Sometimes the child gets his/her eye watering and with secretion, and this may be a chemical conjunctivitis, because of Credé. (E5)

\section{Practice of nursing professionals in the prophylaxis of ophthalmia neonatorum}

There is consensus among participants that the application of silver nitrate takes place in the institution's delivery room. In addition, there is a uniformity among twelve participants about the indication of the prophylactic agent for all neonates, both vaginal birth and cesarean section birth.

In the past, it was used more for vaginal delivery, because of the passage of the child through the canal. Now, in all the institutions they use it for both vaginal birth and cesarean section birth. (E5)

Only two professionals stated that the procedure is performed only in newborns of vaginal birth.

I think, normally, it is used for vaginal birth, I don't know about cesarean section birth, normally it is vaginal, yes. (TE4)

On the local application of silver nitrate at $1 \%$, the grouping of the testimonies allowed to recognize that fourteen professionals claimed that the instillation of the solution happens soon after the birth and is performed in the eyes of the newborn, without specifying the ocular region. Eight participants also said that, in addition to the eye, the application occurs in the genitals in female babies. In both regions, most participants, in this case thirteen nursing professionals, declared the instillation of a drop.

One drop in each eye and one drop on the vagina. (TE2) For female babies, in the vagina and in the eye. For male babies, only in the eye. (AE1)

Only one nurse mistakenly suggested that the application of two drops of silver nitrate at 1\%: Two drops in each eye, right? (E1)

The care performed before the application of Credé's Method was mentioned in the statements of four professionals. According to the them, the hygiene of the newborn is first performed with dry gauze and sterile compress; in addition, the date of expiry of the product is evaluated, as well as its concentration and dilution. 
Once the baby is born, we sanitize using the gauze and sterile compress.[...] We clean all the baby's face. (AE1)

The first thing is to check the date of expiry of the product, and if it is in the correct percentage, if it is diluted. (TE7)

However, a Nursing technician used saline solution to remove the vernix caseosa: I cleaned the child's eye with a gauze [...] passed on a saline solution [...] to remove the vernix that is born in the whole body. (TE3)

Regarding the care performed during the procedure, six participants cited only the application directly to the eye. A Nursing technician mentioned the observation of the instillation site and a nurse said that the solution of silver nitrate at $1 \%$ should be inserted in the corner of the eye and an eyelid massage should be given.

We apply it, there's not much attention to it, but it should be, right? (TE5)

I applied it to the conjunctiva, opened the baby's eyes and applied a drop in each eye. (TE3)

During the application, we must observe if the drop reached the eyeball. (TE7)

You put at the corner (of the eye) and rub a little bit. (E2)

Four professionals did not associate any specific care after the procedure and one of them also stressed the non-use of the saline solution for hygiene, because, in his opinion, it could burn the skin of the newborn.

\section{After that, there's no care at all. (E1) \\ After the application you can't clean with saline solution, you may burn the baby's skin. (TE6)}

Three professionals mentioned the importance of hygiene after the instillation of silver nitrate, but only one specified the way of doing it, from the corner of the eye to inside. In addition, one of them also rescued in his speech the possibility of irritating the baby's skin if the cleaning is not carried out of the correct form, since the solution must be applied only in the eyes. No professional has specified the solution used for hygiene.

After the application, you have to clean around the eyes because [...] it can irritate the baby's skin. [...] Let the solution stay only in the eye. (TE3)

You have to clean not to fall onto the skin, to remain in the eye, and when you clean it is always from the corner of the eye to the inside. (E5)

Finally, the fourteen professionals interviewed reported that they did not receive any courses or specific training to perform the prophylaxis of ophthalmia neonatorum. Four participants also stated that they learned only by observing the procedure in the institutional practice in the sector in which they were inserted, with other members of the team.

We do the general, nothing specific. (E4)

I learned by observing. (TE7)

They taught me how to do it when I went to the nursery, the Nursing technique taught me how, but real training I didn't receive. (TE3)

\section{DISCUSSION}

The findings of research showed a mixture of knowledge and questions among participants related to ophthalmia neonatorum, including its causes, prevention, treatment, possible complications, and its prophylactic methods.

As for the causes, the participants almost exclusively made their association with gonorrhea, since only one nurse mentioned chlamydia. Thus, the professionals proved to be unaware of other bacterial, viral and chemical agents that can cause this infection.

This study shows that, despite it has been associated with Neisseria gonorrhoeae for a long time, Chlamydia trachomatis is the main and most common etiologic agent, mainly in industrialized countries. It is estimated that mothers infected with these bacteria have a $50 \%$ to $75 \%$ chance of transmitting it to their newborn, not only in the ocular region, but also in the nasopharynx, rectum and vagina, and from $30 \%$ to $50 \%$ of newborns will develop conjunctivitis. ${ }^{3}$

It should be noted that other bacteria not characterized as STIs also cause ophthalmia neonatorum, representing from $30 \%$ to $50 \%$ of the cases, such as Haemophilus species, Streptococcus pneumonia, Staphylococcus aureus, Staphylococcus epidermidis, Streptococcus viridans, Escherichia coli, Enterococcus and Pseudomonas aeruginosa, and the latter may also lead to blindness. The viral form is caused by herpes simplex virus and adenovirus, with lymphadenopathy associated with $50 \%$ of the cases. ${ }^{3}$

There is also chemical pink eye (conjunctivitis) associated with the use of silver nitrate and, secondarily, erythromycin and tetracycline. In addition, its appearance may also occur using silver vitelinate at $10 \%$ and iodopovidone at $2.5 \%$, however, with a lower incidence. ${ }^{1,3}$ This lack of knowledge may lead to questions and divergences in the care practice regarding the prophylaxis and management of this infection.

Regarding prevention, most professionals cited only silver nitrate, Credé's Method, as an adequate substance for the prophylaxis of ophthalmia neonatorum, which was used in the setting institution. This finding reveals a gap between the scientific knowledge produced and its translation to clinical practice in health, since nitrate, although long used as a first choice method, has proven toxicity and prophylaxis only against gonococcal conjunctivitis, which led to the discovery of other less toxic and proven methods that are used in other countries, including Brazil, $1,2,4,7,8,10$ but were not even reported by the study participants. 
It should be emphasized that the choice of prophylactic method of ophthalmia neonatorum varies according to the epidemiological reality and the legislation of each country, which has not excluded the possibility of divergences in recommendations and obviously in the practices of the health services. For example, the Brazilian Ministry of Health, in the National Guidelines for Assistance to Normal Delivery (Diretrizes Nacionais de Assistência ao Parto Normal), indicates the use of erythromycin ointment at $0.5 \%$ and tetracycline ointment at $1 \%$, in detriment of the use of silver nitrate at $1 \%$. However, it still allows its use when the service does not have other substances. ${ }^{10}$ Notwithstanding, the Ocular Health Guidelines for Childhood (Diretrizes de Saúde Ocular na Infância), from the same Ministry, have begun to recommend the use of iodopovidone at $2.5 \%$ instead of nitrate..$^{15}$ Such disagreements reinforce the heterogeneity of this practice in maternity hospitals. ${ }^{16}$

Although the study participants point out the prophylaxis used in their practices, there is a lack of knowledge regarding other prophylactic substances. In addition, none of them signaled the importance of prevention, early detection and/or timely treatment of STIs of pregnant women and their sexual partners. ${ }^{7}$

It is known that, although there are other forms of contamination, this group of diseases are the most common ways to acquire ophthalmia neonatorum, so if the pregnant women has an adequate prenatal testing, ${ }^{7}$ with the identification of infectious agents, the groups of risks for proper control and treatment during pregnancy will be identified, thus minimizing the infection of the newborn and promoting the consequent reassessment of prophylactic methods. . $^{9,17}$

Thus, it is observed that the discussion about the prevention of ophthalmia neonatorum should not be restricted to a moment referring to the first care of the newborn in the obstetric center, and should also include preventive and control actions of STIs before their birth.

A mixture of knowledge and questions was also evidenced in the forms of ophthalmia neonatorum treatments, since some professionals did not know the subject and others demonstrated partial knowledge about this issue. The Nursing team needs to know the available treatments, since it plays a prominent role in the drug therapy, being responsible for the preparation and administration of drugs, including neonatology, ${ }^{18}$ besides acting in the orientation of the relatives of the new-born on the use of medications prescribed by the medical staff. ${ }^{19}$

Only two nurses highlighted the need for culture examination and one signaled its absence at the institution. However, the choice of different interventions depends on the type and cause of the infection, identified by this type of examination, but if there are no specific tests, all neonatal conjunctivitis should be treated for chlamydia and gonorrhea, and ceftriaxone 25 to $50 \mathrm{mg} / \mathrm{kg}$ should be recommended, intramuscularly or intravenously, and in Brazil the indicated route is the first. The use of topical treatment is discouraged. 6,7

For viral forms, the international literature indicates acyclovir $(60 \mathrm{mg} / \mathrm{kg})$ concomitantly with a topical ophthalmic solution. Since chemical conjunctivitis, as it manifests itself in a self-limited manner, does not require diagnostic tests or treatment. ${ }^{3}$ And, in addition to the treatment of the newborn, it is necessary to identify and treat the mother and her sexual partner, ${ }^{4,6,7}$ which was not signaled by the professionals, and may also have implications in the practice of care, inasmuch as therapeutic guidelines and recommendations in this area may not be given during the discharge process.

Important data from research are the lack of knowledge and the questions of most of participants regarding the complications of ophthalmia neonatorum, considering the complexity and severity of the infection, which may have blindness as the worst complication due to corneal perforation, noting that blind children are more likely to die in early childhood than healthy children. ${ }^{4}$ In addition to the site complications, systemic complications may also occur in the newborn, such as arthritis and meningitis, and less severe ones such as rhinitis, vaginitis, and urethritis. ${ }^{7}$

The findings indicate limitations in clinical practice, but they point out the importance of the Nursing team adopting good practices in the care of the newborn, based on up-to-date scientific knowledge, thus promoting safe, comprehensive and qualified care. ${ }^{16}$

Pertinent to the concentration of silver nitrate, most professionals did not know how to answer correctly, even there was the wrong reference of $2 \%$. It is worth mentioning that the adequate concentration of nitrate is between $0.95 \%$ and $1.05 \%$, because higher values make the solution more caustic and toxic to the newborn. In addition, their elevations are directly related to more cases of chemical conjunctivitis and may lead to blindness due to opacification of the cornea. ${ }^{2}$ Thus, the knowledge of professionals about the correct concentration of the solution prevents serious misconceptions about its administration, which can seriously damage the newborn.

None of the professionals interviewed knew how to correctly respond to the silver nitrate bottle replacement time, showing that they do not change it within the recommended time to ensure effectiveness in preventing ophthalmia neonatorum and not creating additional damage to the newborn. Study reveals that the recommended time for its change is between 24 and 48 hours, in addition, given the instability of its components and causticity by increasing evaporation, it must be potted in dark neutral glass with an eyedropper device and stored away from light and heat. ${ }^{2}$

Professionals mostly stated that they did not know the complications inherent to the use of silver nitrate, and some suggested only a few clinical manifestations. The most common complication of the use of the solution is chemical conjunctivitis, which can be healed within 48 hours, on average. ${ }^{3}$ Despite limited clinical manifestations, this aggravation causes anxiety to mothers, ${ }^{2}$ and, because of these effects, many countries have replaced it by other solutions. ${ }^{4,7,8,17}$

Professionals claimed in their statements the application of silver nitrate in all types of births, which corroborates the recommendations of the Ministry of Health, ${ }^{11}$ but this question 
still raises questions to professionals, since for a long time it was only used in vaginal births. ${ }^{16}$ The inclusion of its use in cesarean births occurred due to the prolonged rupture time of membranes, since the baby has a risk of coming into contact with the mother's contaminated secretions by ascending pathways that may go unnoticed. ${ }^{16}$ Nevertheless, if this rupture occurred in less than 3 hours, it would not be necessary to apply it. ${ }^{1}$

Regarding the application site of the solution, all participants mentioned the eyes without specifying the location, and a few others also mentioned the vagina in female newborns. The Ministry of Health says that the application of the prophylactic solution should be a drop in the lacrimal sac of each conjunctiva of the newborn. ${ }^{11}$ However, a study pointed out that health professionals still have questions about the exact location for the application of prophylaxis of ophthalmia neonatorum, whether in the corner of the eye or in the conjunctival sac. ${ }^{16}$ It is noteworthy that no scientific evidence was found on the need to use silver nitrate in the neonate's vagina after birth, although this is a recurrent practice in health services, including, in the study scenario.

The number of drops was mentioned as one in each eye by professionals, only one nurse mentioned two. The Ministry of Health, in its Health Care Guidelines for the Newborn, corroborates that the number of drops is one in each lacrimal sac, ${ }^{11}$ but divergences are found in the Brazilian Pharmacopoeia, since the National Health Surveillance Agency mentions the use of two drops in each eye after birth..$^{20}$ Once again, it is important to point out the importance of procedural standardization to avoid that divergences in the guidelines lead to misunderstandings in the practice of care, causing possible complications to the health of the newborn, overdoses or insufficient dosages.

There was no uniformity in the speeches as to care before, during and after the procedure. Care performed prior to the application of silver nitrate should be initiated by removing the vernix caseosa from the ocular region with a dry gauze or moistened with water, not using saline solutions or any other. ${ }^{11}$ Another study, however, showed that irrigation in the eye of the newborn should not be conducted with saline solution; only gauze or cotton to prevent slippage of the hand during the application. ${ }^{16}$ This reinforces the contradictions related to the prophylaxis of ophthalmia neonatorum and the importance of revising practices, including legal recommendations.

During the procedure, the professional should pay attention to the correct application of the solution in the lacrimal sac of the conjunctiva by lightly trailing the lower eyelids down, besides giving a massage on the eyeball for better distribution; if there is any question about the correct instillation inside the eyes, repeat the procedure. After this, it is necessary to perform the hygiene, with a dry gauze, of the excess that remains around the eyes. ${ }^{11}$ It is verified, therefore, the need for training professionals as for the care that permeates the performance of this technique in a correct and safe way, considering that they were not adequately described by professionals.
In this context, all interviewed professionals reported that they did not receive specific courses or training to perform the procedure, which corroborates the knowledge gaps and the practice of prophylaxis of ophthalmia neonatorum and divergences and failures pointed out in the scientific literature, ${ }^{1,16}$ which may cause risk to the health of the newborn.

Therefore, the development of group educational practices among professionals, including nurses, emerges as a possibility for the problematization and critical reflection of daily health practices in the care of the newborn, so that the knowledge can be created and recreated, envisioning its transformation and innovation. ${ }^{21}$ As the dialogue between peers and the constant reflection on the daily work process, like the culture circles, each professional becomes a dynamic and reflexive subject, being able to contribute to changes in the practice.22

Thus, the implementation of permanent education in health services presupposes the possibility of creating spaces for reflection on professional practice, updating professionals based on the best scientific evidence. ${ }^{23}$ Thus, the need for training health professionals is urgent, including the Nursing team, and the revision of government manuals and guidelines, as well as a rethinking of the institutional behaviors related to the prophylaxis of ophthalmia neonatorum, so that clinical practice is based on the best scientific evidence on the subject, with the greater aim of promoting a healthy and harmonious child development.

\section{CONCLUSIONS}

The study evidenced gaps in the knowledge of Nursing professionals related to ophthalmia neonatorum, silver nitrate and the instillation procedure of this prophylactic solution in the newborn, as well as divergences in care practice regarding care before, during and after the procedure. This shows an assistance practice that is not based on up-to-date scientific knowledge but on the reproduction of pre-established techniques and routines that are sometimes wrong.

Data point to the need for training the Nursing team to perform the procedure, given its importance for reducing visual loss in the child population, as well as minimizing additional damage to the health of the newborn. The study also stresses the importance of adequate follow-up of pregnant women in prenatal care with a focus on prevention, early identification and timely treatment of diseases, such as STIs, that may harm the health of both the expectant mother and the future newborn.

It is also expected that the study will contribute with relevant information about ophthalmia neonatorum, such as the presentation of different prophylactic methods, due to the lack of research on the subject, including for the rethinking of guidelines and behaviors in the health care of the newborn.

The limitation of research lies in the description of the phenomenon studied from a single institutional reality, which still uses a prophylactic method whose use is controversial, and it is not possible to generalize the data to the practices of other professionals and other institutions. 


\section{REFERENCES}

1. Netto AA, Goedert ME. Avaliação da aplicabilidade e do custo da profilaxia da oftalmia neonatal em maternidades da grande Florianópolis. Rev Bras Oftalmol [Internet]. 2009 Sep/Oct; [cited 2017 Dec 17]; 68(5):264-70. Available from: http://www.scielo.br/pdf/rbof/ v68n5/a03v68n5.pdf

2. Passos AF, Agostini FS. Conjuntivite neonatal com ênfase na sua prevenção. Rev Bras Oftalmo [Internet]. 2011 Jan/Feb; [cited 2017 Dec 17]; 70(1):57-67. Available from: http://www.scielo.br/pdf/rbof/v70n1/12. pdf

3. Matejcek A, Goldman RD. Treatment and prevention of oftalmia neonatorum. Can Fam Physician [Internet]. 2013 Nov; [cited 2018 Jan 21]; 59(11):1187-90. Available from: https://www.ncbi.nlm.nih.gov/pmc/ articles/PMC3828094/

4. Malik ANJ, Mafwiri M, Gilbert C. Integrating primary eye care into global child health policies. Arch Dis Child [Internet]. 2018; [cited 2018 Apr 24]; 103(2):176-80. Available from: https://adc.bmj.com/content/103/2/176

5. Marchezini RMR, Oliveira DAM, Fagundes LJ, Ciosak SI. As infecções sexualmente transmissíveis em serviço especializado: quais são e quem as tem? Rev Enferm UFPE On Line. [Internet]. 2018 Jan; [cited 2018 Jan 25]; 12(1):137-49. Available from: https://periodicos.ufpe.br/ revistas/revistaenfermagem/article/viewFile/25088/25914

6. Ministério da Saúde (BR). Secretaria de Vigilância em Saúde. Departamento de DST, Aids e Hepatites Virais. Protocolo Clínico e Diretrizes Terapêuticas para Atenção Integral às Pessoas com Infecções Sexualmente Transmissíveis. Brasília (DF): Ministério da Saúde; 2015 [cited 2018 Jun 20]. 120 p. Available from: http://bvsms.saude.gov.br/ bvs/publicacoes/protocolo_clinico_diretrizes_terapeutica_atencao_ integral_pessoas_infeccoes_sexualmente_transmissiveis.pdf

7. Workowski KA, Bolan GA; Centers for Disease Control and Prevention Sexually transmitted diseases treatment guidelines, 2015. MMWR Recomm Rep [Internet]. 2015 Jun; [cited 2018 Aug 30]; 64(RR-03):1-137. Available from: https://www.ncbi.nlm.nih.gov/pmc/articles/PMC5885289/

8. Darling EK, McDonald H. A meta-analysis of the efficacy of ocular prophylactic agents used for the prevention of gonococcal and chlamydial ophthalmia neonatorum. J Midwifery Womens Health [Internet]. 2010 Aug; [cited 2018 Jun 20]; 55(4):319-27. Available from: https://www.ncbi.nlm.nih.gov/pubmed/20630358

9. Comité Consultivo de Infecciones Neonatales. Racionalidad de la profilaxis ocular de la oftalmia neonatal en el recién nacido. Rev Chil Infectol [Internet]. 2017 Jun; [cited 2018 Aug 30]; 34(3):257-8. Available from: https://scielo.conicyt.cl/scielo.php?script=sci_arttext\& pid=S0716-10182017000300008

10. Ministério da Saúde (BR). Secretaria de Ciência, Tecnologia e Insumos Estratégicos. Departamento de Gestão e Incorporação de Tecnologias em Saúde. Diretrizes Nacionais de Assistência ao Parto Normal: versão resumida. $1^{a}$ ed. Brasília (DF): Ministério da Saúde; 2017 [cited 2018 Jun 20].51 p. Available from: http://bvsms.saude.gov.br/bvs/publicacoes/ diretrizes_nacionais_assistencia_parto_normal.pdf

11. Ministério da Saúde (BR). Secretaria de Atenção à Saúde. Departamento de Ações Programáticas Estratégicas. Atenção à saúde do recém-nascido: guia para os profissionais de saúde. $2^{\mathrm{a}}$ ed. Brasília (DF): Ministério da Saúde; 2014 [cited 2018 Apr 14]. 194 p. Available from: http://bvsms. saude.gov.br/bvs/publicacoes/atencao_saude_recem_nascido_v1.pdf
12. Minayo MCS. Análise qualitativa: teoria, passos e fidedignidade. Ciênc Saúde Coletiva [Internet]. 2012 Mar; [cited 2018 Aug 30]; 17(3):621-6. Available from: http://www.scielo.br/scielo.php?script=sci_ arttext\&pid=S1413-81232012000300007\&Ing=en\&nrm=iso\&tIng=pt

13. Fontanella BJB, Magdaleno Júnior R. Saturação teórica em pesquisas qualitativas: contribuições psicanalíticas. Psicol Estud [Internet]. 2012 Jan/Mar; [cited 2018 Aug 25]; 17(1):63-71. Available from: http://www. redalyc.org/articulo.oa?id $=287123554008$

14. Oliveira DC. Análise de conteúdo temático-categorial: uma proposta de sistematização. Rev Enferm UERJ [Internet]. 2008 Oct/Dec; [cited 2018 Aug 30]; 16(4):569-76. Available from: http://www.facenf.uerj.br/v16n4/ v16n4a19.pdf

15. Ministério da Saúde (BR). Secretaria de Atenção à Saúde. Diretrizes de Atenção à Saúde Ocular na Infância: detecção e intervenção precoce para prevenção de deficiências visuais. $2^{a}$ ed. Brasília (DF): Ministério da Saúde; 2013 [cited 2018 Jun 20]. 40 p. Available from: http://bvsms. saude.gov.br/bvs/publicacoes/diretrizes_atencao_saude_ocular_ infancia.pdf

16. Müller EB, Zampieri MFM. Divergências de cuidados ao recém-nascido no centro obstétrico. Esc Anna Nery [Internet]. 2014 Apr/Jun; [cited 2018 Jun 20]; 18(2):247-56. Available from: http://www.scielo.br/pdf/ ean/v18n2/1414-8145-ean-18-02-0247.pdf

17. Schaller UC, Klauss V. Is Crede's prophylaxis for ophthalmia neonatorum still valid? Bull World Health Organ [Internet]. 2001; [cited 2018 Jun 20] 79(3):262-3. Available from: https://www.ncbi.nlm.nih.gov/pmc/articles/ PMC2566367/pdf/11285676.pdf

18. Gaíva MAM, Souza JS. Erros de administração de medicamentos em unidades de terapia intensiva neonatal. Cienc Cuid Saude [Internet] $2015 \mathrm{Jul} / \mathrm{Sep}$; [cited $2018 \mathrm{Jul} 1$ 1]; 14(3):1330-8. [aprox. 5 telas]. Available from: http://periodicos.uem.br/ojs/index.php/CiencCuidSaude/article/ view/25445

19. Alcântara KL, Brito LLMS, Costa DVS, Façanha APM, Ximenes LB, Dodt RCM. Orientações familiares necessárias para uma alta hospitalar segura do recém-nascido prematuro: revisão integrativa. Rev Enferm UFPE On Line [Internet]. 2017 Feb; [cited 2018 Jul 1]; 11(2):645-5. Available from: http://pesquisa.bvs.br/brasil/resource/pt/bde-30520

20. Ministério da Saúde (BR). Agência Nacional de Vigilância Sanitária. Formulário Nacional da Farmacopeia Brasileira. $2^{\mathrm{a}}$ ed. Brasília (DF): Anvisa; 2012.

21. Müller EB, Zampieri MFM. Prática educativa com enfermeiras visando o cuidado humanizado ao recém-nascido no centro obstétrico. Texto Contexto Enferm [Internet]. $2014 \mathrm{Jul} / \mathrm{Sep}$; [cited 2018 Aug 30];23(3):78290. Available from: http://www.scielo.br/pdf/tce/v23n3/pt_0104-0707tce-23-03-00782.pdf

22. Silva LHF, Santo FHE, Chibante CLP, Paiva ED. Educação permanente em unidade neonatal a partir de círculos de cultura. Rev Bras Enferm [Internet]. 2018; [cited 2018 Aug 30]; 71(Suppl. 3):1328-33. Available from: http://www.scielo.br/scielo.php?script=sci_arttext\&pid=S0034$71672018000901328 \& \operatorname{lng}=e n \& n r m=i s o \& t \mid n g=p t$

23. Lima AM, Castro JFL. Educação permanente em saúde: uma estratégia para a melhoria das práticas obstétricas. Enferm Obstet [Internet]. 2017; [cited 2018 Aug 30]; 4:e56. Available from: http://www.enfo.com.br/ojs/ index.php/EnfObst/article/view/56/55

${ }^{a}$ Article extracted from the final paper of the Nursing undergraduate course of the Universidade Federal Fluminense, Rio das Ostras, authored by the first author, under the orientation of the second author. Title: Knowledge and Practice of Nursing Professionals about Prophylaxis of Ophthalmia Neonatorum. Year: 2018. 